\title{
Borges y García Márquez: nuestro Apolo y nuestro Dioniso
}

\author{
Borges and García Márquez: our Apollo and our Dionysus
}

Garcia Marquez e Borges: o nosso Apolo e o nosso Dionisio

\section{Jorge Volpi}

Doctor en Filología Hispánica de la Universidad de Salamanca,

España. Autor de Memorial del engaño (Alfaguara, 2014), No será la tierra (Alfaguara, 2006), El juego del apocalipsis (Plaza

y Janés, 2001), En busca de Klingsor (Seix Barral, 1999), El

temperamento melancólico (Nueva Imagen, 1996), entre otros.

Documento accesible en línea desde la siguiente dirección: http://revistas.javeriana.edu.co

doi:10.11144/Javeriana.CL18-36.bygm

\section{Cómo citar este texto:}

Volpi,Jorge. "Borges y García Márquez: nuestro Apolo y nuestro Dioniso". Cuadernos de Literatura 18.36 (2014): 123-125. http://dx.doi.org/10.11144/Javeriana.CL18-36.bygm 
UNA VEZ QUE se extingan las ceremonias fúnebres y se adormezca el duelo, que se agoten los homenajes y las exequias, y se desdoren las figuras públicas y se olviden las antipatías abruptas o las declaraciones estertóreas, se volverá una convicción natural lo que algunos han vaticinado desde hace décadas: que los dos colosos surgidos de esa brillantísima Edad de Oro de la narrativa latinoamericana que se prolongó durante la segunda mitad del siglo XX fueron Jorge Luis Borges y Gabriel García Márquez. Los dos escritores más influyentes y poderosos de nuestra región y nuestra lengua. Los dos más admirados e imitados en el orbe. En ese juego de dualidades que tanto nos gusta, nuestro Platón y nuestro Aristóteles. O, mejor, nuestro Apolo y nuestro Dioniso.

Sin duda fueron acompañados por una asombrosa cohorte de titanes, con poéticas al gusto de cada uno, de Rulfo a Vargas Llosa, de Donoso a Fuentes, de Sábato a Ibargüengoitia, de Ribeyro a Cortázar, pero las voces más oídas, más singulares, más originales —si entendemos por originalidad una mutación insólita entre las enseñanzas del pasado y la serena rivalidad con sus contemporáneos- fueron las del poeta y cuentista argentino y las del cuentista y novelista colombiano, suma de todos los esfuerzos que los precedieron, de Machado de Assis y Jorge Isaacs a Macedonio Fernández y Alfonso Reyes, y umbrales de todos aquellos que los han seguido, de Roberto Bolaño a quienes hoy publican, a su sombra, sus primeros libros.

A la distancia no podrían parecer más contrarios, más distantes. De un lado, el escritor ciego y puntilloso, tan acerado como melancólico, hierático hasta casi fungir como profeta, dueño de un sutilísimo humor aún malentendido, el hombre cercano - a su pesar - a la derecha, el vate unánimemente venerado que jamás recibiría el Nobel. Del otro, el escritor jacarandoso y bullanguero, tan dotado para desenrollar la sintaxis como para reconducir los mitos, sonriente hasta convertirse en amigo de todas las familias - esas que sin conocerlo hoy sin pudor lo llaman Gabo-, el hombre cercano a la izquierda y a Fidel Castro, el bardo unánimemente adorado que recibió el Nobel más joven que ningún otro en América Latina.

Sí: en lontananza encarnan vías antagónicas. Borges es, evidentemente, el apolíneo. El escultor que pule cada arista y cada ángulo. El prestidigitador que obsesivamente trastoca cada adjetivo y cada adverbio. El criminal que siempre esconde la mano. El modesto anciano que odia los espejos y la cópula y sin embargo multiplica los Borges a puñados. El detective que en su búsqueda esconde que al mismo tiempo es el criminal. El filósofo nominalista y el físico cuántico que se pierde en la Enciclopedia. El autor de las paradojas y bucles más aventajado desde Zenón. García Márquez es, en cambio, el dionisíaco. El torrencial demiurgo 
de genealogías y prodigios. El audaz dispensador de metáforas y laberintos de palabras. El cartógrafo de la jungla y el cronista de nuestra circular cadena de infortunios. El ídolo sonriente que trasforma la Historia - y en especial la sórdida trama colombiana - en mil historias entrecruzadas, tan tiernas y atroces como inolvidables. El bailarín que, al conducirnos a la pista, nos obliga a seguir su hipnótico ritmo a rajatabla. El sagaz escriba que se burla de los tiranuelos con los que tanto ha convivido. El desmadrado cuentero que finge no seguir regla alguna fuera de su imaginación, excepto las que él mismo se - y nos-impone.

Apolo y Dioniso. Y sin embargo estas dos vías, como ya apuntaba Nietzsche, no son excluyentes sino complementarias. Las dos mitades del mundo. De nuestro mundo. Para empezar, García Márquez no hubiese escrito como García Márquez sin aprender de Borges, su predecesor y su maestro. Y Borges no habría encontrado mejor continuador que este discípulo rejego, dispuesto no a copiar sus trucos o su doctrina sino a usarlos en su provecho para huir de la Academia y fundar una nueva, exitosísima escuela, el realismo mágico. Ninguno tiene la culpa, por supuesto, de su ingente legión de copistas: sus invenciones resultaban demasiado deslumbrantes como para que cientos de salteadores de caminos no quisieran agenciárselas.

Los dos han sido justamente elevados a los altares. O, mejor aún, a los altares privados que cada uno erige en su hogar: son nuestros penates. Imposible no adorarlos y no querer, a la vez, descabezarlos. Imposible no aspirar a reiterar -Vargas Llosa dixit-su deicidio. 